\title{
MOVIMENTO SOCIAL NEGRO (MSN) E RELIGIÕES AFRO- BRASILEIRAS: QUESTÕES IDENTITÁRIAS E A PROMOÇÃO DA IGUALDADE RACIAL
}

\author{
Black social movement (MSN) and afro-brazilian religions: identity issues \\ and the promotion of racial equality
}

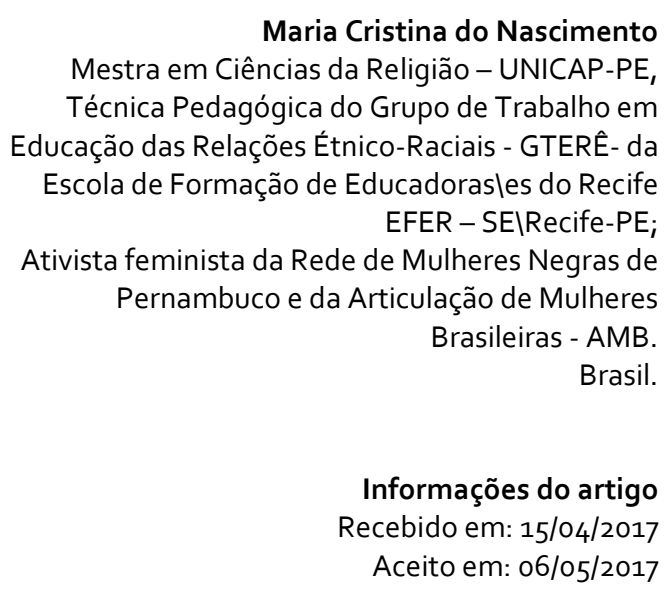

Maria Cristina do Nascimento

Mestra em Ciências da Religião - UNICAP-PE, Ténica Pedagogica do Grupo de Trabalho em ducação das Relações Étnico-Raciais - GTERÊ- da EFER - SE|Recife-PE; Recebido em: 15/04/2017

\begin{abstract}
Resumo
Este artigo é parte significativa da pesquisa de mestrado Políticas Públicas com Axé: religiões afrobrasileiras e a promoção da igualdade racial (demandas para a educação do Recife), nele destacamos as interfaces entre o Movimento Social Negro e as Religiões Afro-brasileiras, como marca de uma ancestralidade resgatada nos anos 70180 (do século passado), analisando a participação das Religiões Afro-brasileiras nas Conferências de Igualdade Racial e, a partir do resgate da memória de sua participação nas Conferências e identificar avanços, dificuldades e resistências na implementação destas políticas. Dialogamos com a interseccionalidade entre as mais diversas formas de atuação na esfera pública das religiões de matrizes africanas, através da experiência de controle social e participação cidadã de mulheres negras e mulheres de terreiro. O Movimento Social Negro tem uma importância indiscutível na luta contra o racismo e por afirmação de direitos da população negra, principalmente por uma educação sem discriminação, no questionamento sobre o mito da democracia racial, incluindo nos anos 70 do século passado as religiões afro-brasileiras como mais um elemento identitário e marco de sua agenda de reivindicações.

Palavras-chave: Movimento Social Negro; Religiões afro-brasileiras; Mulheres negras; Mulheres de terreiro; Políticas de Promoção da Igualdade Racial.
\end{abstract}

\section{Introdução}

O Movimento Social Negro (MSN) nasce da luta por libertação a partir de estratégias de fuga e resistência cultural, sua trajetória é longa e com fortes momentos, apagamentos históricos e revigoramentos, que aponta erros históricos, denuncia e demarca espaços de reivindicação de direitos. De modo geral, a definição dada por Joel Rufino dos Santos corrobora com essa percepção:

[...] todas as entidades, de qualquer natureza, e todas as ações, de qualquer tempo [aí compreendidas mesmo aquelas que visavam à autodefesa física e cultural do negro], fundado e promovido por pretos e negros [...]. Entidades religiosas [como terreiros de candomblé, por exemplo], assistenciais [como as confrarias coloniais], recreativas [como "clubes de negros"], artísticas 
[como os inúmeros grupos de dança, capoeira, teatro, poesia], culturais [como os diversos "centros de pesquisa"] e políticas [como o Movimento NEGRO Unificado]; e ações de mobilização política, de protesto antidiscriminatório, de aquilombamento, de rebeldia armada, de movimentos artísticos, literários e 'folclóricos' - toda essa complexa dinâmica, ostensiva ou encoberta, extemporânea ou cotidiana, constitui movimento negro (SANTOS, J.R., 1994, p. 157).

\section{Para Luiz Alberto O. Gonçalves,}

O movimento negro, desde sua origem, se constitui como um ator dividido entre tradição e modernidade, resistência e liberdade. É, pois, dessa forma que ele "projeta os negros na História". Mas não só. É assim que ele contribuiu na modernização da sociedade brasileira, questionando suas crenças e ideologias raciais, propondo outras imagens de sua composição étnica, enfim, tensionando continuamente a relação entre sujeito e sistema (GONÇALVES, 1998, p. 43).

Dessa forma, o movimento social negro não foi apenas um esforço de transformar aslos negraslos em "atores virtuais", mas afirma-los enquanto atores políticos, com suas práticas norteadas por modelos culturais. Gonçalves (1998) sintetiza a história do MSN a partir dos anos 20 e 30, do século passado, focados no modelo liberal, nos anos 1940 e 1950, no modelo populista e nos anos 1970 e 1980, na desintegração do modelo técnico-militar, advindo da ditadura militar, esse período terá centralidade nesse artigo.

Nosso enfoque dialoga com a interseccionalidade (raça, gênero, religião) compreendendo que as desigualdades em seus diversos aspectos se entrecruzam e se sobrepõem atingindo de maneiras específicas os sujeitos, assim, as formas de atuação na esfera pública das religiões de matrizes africanas e indígenas vêm dialogando com o movimento social ${ }^{1}$ negro e com o feminismo, na luta contra o racismo, sexismo e a intolerância religiosa.

Kimberle Crenshaw (2002) sugere que, na verdade, nem sempre lidamos com grupos distintos de pessoas e sim com grupos sobrepostos (racial, gênero, geracional, deficiências, sexualidades), nesse sentido parte do projeto da interseccionalidade, proposto pela autora e ativista norte americana, visa incluir questões raciais nos debates sobre gênero e direitos

\footnotetext{
1 Ilse Sherer-Warren (1998) conceitua os movimentos sociais contemporâneos como redes sociais complexas que se conectam, de forma simbólica e solidária, sujeitos e atores coletivos que vão construindo suas identidades num processo dialógico de identificações éticas e culturais, a partir de intercâmbios, negociações, resoluções de conflitos e de resistência aos mecanismos de exclusão sistêmica na globalização, com implicações no sentimento coletivo acerca das dificuldades, desafios e possibilidades de realizar política e emocionalmente sua condição de sujeito.
} 
humanos e incluir questões de gênero nos debates sobre raça e direitos humanos e outras identidades. O movimento de mulheres negras vem sistematicamente assinalando a necessidade desse olhar interseccional em relação às questões específicas das mulheres negras e suas implicações nas políticas públicas para as mulheres e na igualdade racial.

Para contextualização histórica das religiões afro-brasileiras, utilizamos o aporte teórico da sociologia, antropologia e história, para uma compreensão de como se estruturaram e se configuram atualmente em Recife. Buscamos estabelecer um diálogo com diversas formas de atuação na esfera pública das religiões de matrizes africanas, permeando o movimento social negro, o movimento de mulheres e o feminismo, na luta contra o racismo e intolerância religiosa.

Como parte da metodologia da pesquisa de cunho qualitativo, a análise documental teve como base as proposições da I Conferência de Igualdade Racial do Recife (CMPPIR) diagnosticando possíveis avanços e ou repetições de demandas nas II e III conferências.

Realizamos 07 entrevistas semiestruturadas, com cerca de cinco (05) horas de gravação do dia 28 de junho ao dia 05 de setembro de 2016, elaboramos um roteiro específico para pessoas de terreiros e outro para a gestão, realizadas com representantes de religiões afro-brasileiras que estiveram presentes nas Conferências de Igualdade Racial, num total de O4 entrevistas, no intuito de construir uma linha histórica com essas memórias e a narrativa documental, vendo as memórias como marco importante na (re) construção da história.

Neste artigo destacamos no primeiro momento as interfaces entre o Movimento Social Negro e as Religiões Afro-brasileiras, como marca de uma ancestralidade resgatada nos anos 1970|80, em seguida faremos uma análise dos processos de Conferências de Promoção da Igualdade Racial, a partir da Nacional, (CONAPIR) destacando a participação das Religiões Afro-brasileiras com olhar específico na Conferência em Recife (CMPPIR) no eixo das religiões e suas proposições, para finalizar, apresentaremos a experiência de controle social e participação cidadã da Rede de Mulheres de Terreiro de Pernambuco como uma das mais diversas formas de atuação na esfera pública das religiões de matrizes africanas como possibilidade e necessidade da interseccionalidade nas políticas de igualdade racial. 


\section{Movimento social negro e pertencimento afro-religioso}

Lívio Sansone (2003) expõe que de 1964 a 1983, momento em que a ditadura militar reprimiu direitos civis e, consequentemente houve desarticulação do MSN, mas que, conforme o autor, nos 10 anos entre $1970-80$ houve um afrouxamento do controle militar e um processo de crescimento e criatividade da cultura e de organizações negras, com trabalhadoras/es negras/os começando a exigir igualdade, com mais interesse em demonstrar o orgulho negro. Para este autor, ainda:

Há duas razões para isso. Por um lado, através da mobilidade social ascendente, uma nova geração de trabalhadores negros deparou com barreiras à cor que não tinham sido percebidas até então, uma vez que as expectativas, em termos de direitos civis, costumavam ser baixas entre os pobres. Por outro lado, esses trabalhadores negros tinham mais tempo e dinheiro para gastar na organização da comunidade e nas atividades de lazer. Formaram-se novos movimentos negros e associações carnavalescas inteiramente negras. A cultura e a religião negras ganharam maior reconhecimento oficial. Particularmente na Bahia, criaram-se formas novas e poderosas de cultura negra [...] elas fizeram eco ao movimento pelos direitos civis nos Estados Unidos e à luta pela independência nas colônias portuguesas da África. A mídia rotulou esse processo de "reafricanização" da Bahia (SANSONE, 2003, p. 43-44).

É nesse período, assinalado por Sansone (2003), que há o surgimento do Movimento Negro Unificado (MNU), que marca a ruptura definitiva entre a dimensão étnica e outras dimensões sociais. Gonçalves (1998) considera que, nesta fase, o projeto do movimento social negro é ambicioso, momento em que associa cidadania e identidade negra, política e cultura, igualdade e direito à diferença, os militantes protestam contra a exclusão socioeconômica da população negra. O mundo da tradição não era mais o mesmo:

As religiões afro-brasileiras haviam sofrido uma transformação muito significativa, a partir do encontro entre religiosos e intelectuais, com vistas a construir uma cosmovisão dos rituais africanos, uma teologia negra. Certos espaços antes considerados exclusivamente "culturais" (ou de lazer) são utilizados enquanto meios de protesto político. Novos temas passam a compor a agenda dos militantes, além dos "velhos" problemas referentes ao mercado de trabalho e acesso à educação; questões tais como violência racial, mulheres negras, cultura juvenil, diversidade cultural e outros serão discutidas nos fóruns de suas organizações. Cada vez mais a prática dos militantes estará marcada por alianças políticas, as mais diferentes possíveis. As divergências internas assumem dimensões gigantescas. $O$ grande desafio a ser enfrentado não é apenas definir uma "linguagem específica" para se comunicar com outros setores sociais, mas criar canais de comunicação entre os próprios segmentos do movimento negro (GONÇALVES, 1998, p. 46-47). 
O MNU lança um manifesto em 1978 e reascende o debate sobre a política de educação com viés antirracista, propõe alçar Zumbi dos Palmares para a categoria de herói nacional e a data de sua morte, 20 de novembro, como o dia de consciência negra, proposta já apresentada por Oliveira Silveira em 1971 (SILVA; GONÇALVES, 2000), o MNU encontra, também na religião, um lugar de reconhecimento e reencontro com os laços com a África.

É, portanto, como corolário do processo de consolidação de uma nova identidade social e cultural para o negro brasileiro que a pertença, ou pelo menos proximidade, com as religiões afrodescendentes passa a ser vista como parte constitutiva do "ser negro" (OLIVEIRA, 2011, p. 52).

O pertencimento religioso afro-brasileiro, como recorte identitário e reafirmação de marca da ancestralidade africana, apresenta-se no posicionamento público, marcante nos espaços universitários e nas ruas, onde o resgate das africanidades é o mote incorporado nesse período, presente em movimentos contestatários e de afirmação da raça. Pernambuco acompanha essa mobilização nacional.

Esse processo está fortemente marcado na memória desde os finais da década de 1980, momento em que o Movimento Negro Unificado se organizou no estado de forma mais efetiva e foi aos terreiros em busca de sua ancestralidade. Juntamente com esse processo político, as transformações na cultura, economia e sociedade levaram os terreiros de xangôs em Pernambuco a repensarem suas práticas, seus rituais, suas indumentárias, entrando em sintonia com os acontecimentos do mundo afro-religioso brasileiro (CAMPOS, 2013, p. 16-17).

A afirmação da negritude acompanhada da religiosidade como uma das marcas de identidade e pertença de uma coletividade negra se fortaleceu nas lutas sociais:

A partir daí fui transar o meu povo mesmo, ou seja, fui transar candomblé, macumba, essas coisas que eu achava que eram primitivas. Manifestações culturais que eu, afinal de contas, com uma formação em Filosofia, transando uma forma cultural ocidental tão sofisticada, claro que não podia olhar como coisas importantes (GONZALEZ, 1994, p. 382).

Estar em movimento, reconhecerem-se e afirmarem-se a partir de sua religiosidade afro-brasileira, assegura, de maneira singular sua identidade cultural, através de uma exposição do corpo, de outro jeito, foi um dos caminhos escolhidos para estar nos espaços públicos e políticos por militantes do $\mathrm{MNU}^{2}$.

\footnotetext{
2 Em Recife a organização de Afoxés constituem um marco dessa aproximação com as religiões afro, além da participação de forma política nos Maracatus, cujas aproximações com as religiões afro é orgânica e anterior ao MNU (LIMA, 2005). Nesse momento o MNU em Pernambuco também estruturou uma imprensa negra, com espaço destinado a discussão sobre religiosidade (DJUMBAY).
} 
Para Sales Jr., (2009), as religiões afro-brasileiras estão no contexto das mobilizações do movimento social negro, a partir da construção de sua agenda política e na elaboração de estratégias de luta contra o racismo e para a promoção de igualdade racial, articulando a valorização da religião afro-brasileira como patrimônio cultural brasileiro e na luta contra a intolerância religiosa. Corrobora com essa perspectiva, Mariana Morais (2012),

Essas religiões tornam-se uma das bases para a construção da identidade nacional e da identidade negra, que ora se entrelaçam ora demarcam suas diferenças demonstrando a ambiguidade presente na dinâmica identitária em um contexto de globalização (MORAIS, 2012, p. 54).

Os anos pós abertura política (1985) trouxeram diversos desafios para os diferentes movimentos sociais e uma maior articulação entre eles, visando a construção de um processo democrático na luta pelas diretas e por uma Constituição com ampla participação popular e avanços nos direitos das chamadas minorias (indígenas, negras, mulheres, crianças, pessoas com deficiências), reafirmação do estado laico, plural e o respeito às liberdades religiosas.

Como resultado a Constituição de 1988 traz o viés da diversidade e avanços no campo democrático, garantia de direitos e a afirmação dos espaços de construção de políticas públicas e controle social.

Uma Carta Aberta, distribuída à população, concitava os negros a formarem "Centros de Luta" nos bairros, nas vilas, nas prisões, nos terreiros de candomblé e umbanda, nos locais de trabalho e nas escolas, a fim de organizar a peleja contra a opressão racial, a violência policial, o desemprego, o subemprego e a marginalização da população negra (DOMINGUES, 2007, p. 114)

Essa articulação entre as agendas vem se estruturando com o resgate das africanidades, ou amefricanidades, como defende Lélia Gonzalez (1988), com o reconhecimento da religião como um dos elementos de identidade negra, bem como, 0 processo de dessincretização dos candomblés (SALES JR., 2009; PRANDI, 2003).

Sales Jr. (2009) refere-se à presença do candomblé nas políticas públicas como um retorno ao mito fundador, como forma de uma ancestralidade difusa:

Nesse contexto, os movimentos sociais negros incorporam em suas narrativas políticas as comunidades religiosas de matriz africana como parte relevante das lutas históricas de emancipação negro-africana no Brasil, um mito de origem que define uma ancestralidade difusa. A identidade "afropopular" ou "negro-africana" implica a equivalência entre as diversas identidades sociais, políticas ou religiosas, do campo afro-brasileiro, e nesse 
caso o inimigo global a ser enfrentado passa a ser muito menos evidente (SALES JR., 2009, p. 129).

Para o autor, ao vincular a identidade afro-brasileira e sua matriz religiosa, o MSN abre espaço para a participação das religiões afro-brasileiras como o Candomblé, na agenda das políticas públicas, a partir de,

Uma ancestralidade comum, mesmo que difusa, é o que estabeleceria uma relação de solidariedade entre o "povo negro" e o "povo de axé", ainda que sem um vínculo iniciático ou ritual. Ancestralidade comum que os faz alvos de modalidades distintas das mesmas práticas racistas contra, de um lado, características físicas aparentes, e, de outro, elementos culturais. Ou seja, um adepto, ainda que branco, de um culto de matriz africana seria objeto de discriminação por sua "crença", assim como uma pessoa negra por sua "cor". [...]Desta forma, ao estabelecer relações e categorias de equivalência, a agenda "negra" constitui-se da conjunção de duas estratégias políticas distintas: de um lado, a valorização da religião afro-brasileira como patrimônio histórico e cultural regional, nacional e, mesmo, internacional, diaspórica, considerada parte de uma política de reparação ou de promoção da igualdade racial; por outro lado, a luta contra a intolerância religiosa, considerada como uma modalidade da discriminação étnico-racial (SALES JR., 2009, p. 130).

Assim militantes afro-religiosasłos passam a circular nos espaços políticos e sociais, através dos movimentos sociais e utilizando de seus recursos organizacionais, unindo força no combate à intolerância racial. Essa articulação de agendas não é livre de conflitos e relações de poder, características inerentes à esfera pública e nas lutas por direitos, um dos aspectos de conflitos refere-se a questão de gênero no interior do movimento negro e a questão de raça no movimento feminista, como determinantes para o surgimento do movimento de mulheres negras no final dos anos 80 e início dos 9o, do séc. XX (CARNEIRO, 1990).

Por ocasião dos 300 anos de Zumbi dos Palmares, em 1995, organizou-se nacionalmente um ato denominado de Marcha Zumbi dos Palmares, culminando com a entrega de uma carta reivindicatória ao Governo Brasileiro, na qual propunha o reconhecimento do racismo brasileiro, e ações efetivas de reparação histórica, dentre elas a legalização das terras quilombolas, legislações e normas que garantam que pessoas negras não sejam discriminadas nas instituições públicas e no mercado de trabalho, o reconhecimento de Zumbi dos Palmares como herói nacional. Resultado da Marcha Zumbi houve a criação do Grupo de Trabalho Interministerial de Valorização da População Negra (GTI População Negra), ligado ao Ministério da Justiça. 
Em 1998, no Programa Nacional de Direitos Humanos (I PNDH), a matriz religiosa afro-brasileira aparece na forma de luta contra a intolerância religiosa, uma resposta às mobilizações do movimento negro nacional.

Em 2001, houve uma forte mobilização nacional para Durban, África do Sul, a caminho da III Conferência Mundial contra o Racismo, e que demandou debates e organização do MSN em todo território nacional.

O Governo brasileiro, a partir das recomendações de Durban, instituiu algumas Políticas públicas que atendem demandas históricas do MSN e das populações de terreiro de religiões afro-brasileiras:

a) Em janeiro de 2003 houve promulgação da Lei $N^{0} 10.639 / 03^{3}$ que determina a obrigatoriedade do ensino da História e Cultura Africana e Afro-brasileira, acrescida a indígena, Lei No 11.645/2008. Em Recife, como uma das ações do PCRI, foi criado o grupo de trabalho das relações étnico-raciais na educação (GTERÊ) para implementação dessa política.

b) Em 21 de março de 2003 foi criada a Secretaria Especial de Políticas de Promoção da Igualdade Racial (SEPPIR) com status de ministério e a função de assessorar diretamente o Presidente da República, acompanhar e coordenar de diferentes órgãos e ministérios; programas de cooperação com organismos públicos, privados, nacionais e internacionais; acompanhar e promover o cumprimento de acordos internacionais assinados pelo Brasil para o combate ao racismo e formas corretas de intolerâncias com vistas à promoção da igualdade racial

c) Em 2007 O decreto no $6.040 \mid 2007^{4}$ instituiu a Política Nacional de Desenvolvimento Sustentável dos Povos e Comunidades Tradicionais...

\footnotetext{
3 Resultado de reivindicação histórica do movimento social negro, como mostra a pesquisa de Maria de Fátima Oliveira Batista (2010), o projeto da referida lei nasceu por iniciativa de ativistas de Pernambuco, foi apresentado em primeira mão pelo Deputado Federal Humberto Costa ainda na década de 1990 e reapresentado pela deputada Esther Grossi e deputado Bem Hur e culminou na Lei 10.639lo3. Em Recife, a incidência do movimento negro de PE também se deu na Lei Orgânica Municipal, Art. 138, que "estabelece a difusão e o ensino de disciplinas referentes à cultura afro-brasileira e indígena e outras vertentes nas escolas públicas municipais", a autora diz que em contraposição o processo de formação da Rede de Ensino do Recife não faz menção à pluralidade cultural. A demanda por uma educação das relações étnico-raciais e para a inclusão da História da África e de História do Negro no Brasil já consta na Declaração da Convenção "O negro na Constituinte" (CNC, 1986) e no documento da Marcha Zumbi dos Palmares (MZP, 1995).

4 Diário Oficial da União - Seção 1 - 8/2/2007, Página 316.
} 
d) O racismo institucional foi pautado a partir do Programa de Combate ao Racismo Institucional $\left.(\mathrm{PCR})^{5}\right)$ implantado no Recife e coordenado pela Diretoria de Igualdade Racial no período de 2005/2012, reeditado em 2015 pela Gerência de Igualdade Racial do Recife;

e) A Portaria nº 992 de 13 de maio de 2009 instituiu a Política de Saúde da População Negra. Todas essas políticas, com exceção das cotas raciais, foram aportadas pelo Estatuto da Igualdade Racial - Lei 12.288/2010, depois de longos anos de embates fervorosos, foi aprovado com uma linguagem que ameniza os danos causados pelo racismo, palavra esta que só aparece duas vezes em todo texto, vale salientar.

O debate sobre as quotas nas universidades gerou muitos posicionamentos contrários e a favor, inclusive com audiência do Supremo Tribunal Federal (STF, 2010) para ouvir as diversas posições e deferir acerca de sua constitucionalidade.

A busca pela visibilidade da religiosidade afro-brasileira nos dados censitários esteve presente nos movimentos sociais negros e de terreiro em 2010 com a campanha: "Quem é de Axé, diz que é", que, dentre outras questões,

A Campanha foi proposta em função de duas grandes motivações. A primeira, como afirmação do pertencimento afro religioso, pois "Quem é de axé diz que é", surgiu em outros estados do país, no ano de 2010, a partir da ação do Coletivo de Entidades Negras, que identificou o número muito pequeno de pessoas, que se declaravam como integrantes de religiões de matrizes africanas nos dados oficiais (LIMA, 2014, p. 8).

Nos censos realizados pelo Instituto Brasileiro de Geografia e Estatísticas (IBGE) em 2000 e em 2010, as religiões afro-brasileiras apresentam um pertencimento de apenas 0,3\% das/os brasileiras/os, que, segundo Reginaldo Prandi (2004), ainda é um resquício das perseguições sofridas por adeptos dessa religião e a múltipla pertença religiosa, característica brasileira:

Quando se trata das religiões afro-brasileiras, as estatísticas sobre os seguidores costumam oferecer números subestimados, o que se deve às circunstâncias históricas nas quais essas religiões surgiram no século XIX, quando o catolicismo era a única religião tolerada no País, a religião oficial, e a fonte básica de legitimidade social. Para se viver no Brasil, mesmo sendo

\footnotetext{
${ }^{5}$ Estabelecido por uma ação de parceria entre: Ministério da Saúde (MS), o Ministério Público Federal (MPF), a Secretaria Especial de Políticas de Promoção da igualdade Racial (SEPPIR), o Programa das Nações Unidas para o Desenvolvimento (PNUD), a Organização Pan-Americana de Saúde (OPAS) e o Ministério do Governo Britânico para o Desenvolvimento Internacional (DFID), sob a supervisão da Agência Brasileira de Cooperação $(A B C)$.
} 
escravo, e principalmente depois, sendo negro livre, era indispensável, antes de mais nada, ser católico. Por isso, os negros que recriaram no Brasil as religiões africanas dos orixás, voduns e inquices se diziam católicos e se comportavam como tais. Além dos rituais de seu ancestrais, frequentavam também os ritos católicos. Continuaram sendo e se dizendo católicos, mesmo com o advento da República, no fim do século XIX, quando o catolicismo perdeu a condição de religião oficial e deixou de ser a única religião tolerada no país (PRANDI, 2004, p. 225).

$\mathrm{Na}$ esfera política brasileira há avanços relevantes em termos de marcos legais para a promoção da igualdade racial. Avanços que são parte fundamental das lutas engendradas pelo MSN, como reparação histórica das desigualdades sociais e raciais na sociedade brasileira e de mudanças na relação com a cultura negra, percebendo que:

[...] a cultura não é só uma viagem de redescoberta, uma viagem de retorno. Não é uma "arqueologia". A cultura é uma produção. Tem sua matéria prima, seus recursos, seu "trabalho produtivo". Depende de um conhecimento da tradição enquanto "o mesmo em mutação" e de um conjunto efetivo de genealogias. Mas o que esse "desvio através de seus passados" faz é nos capacitar, através da cultura, a nos produzir a nós mesmos de novo, como novos tipos de sujeitos. Portanto, não é uma questão do que as tradições fazem de nós, mas daquilo que nós fazemos das nossas tradições. Paradoxalmente nossas identidades culturais, em qualquer forma acabada, estão à nossa frente. Estamos sempre em processo de formação cultural. A cultural não é uma questão de ontologia, de ser, mas de se tornar (HALL, 2008, p. 43).

O MSN atualmente se constitui de uma pluralidade de configurações em face da globalização e do neoliberalismo, para Gonçalves (1998):

Temas não suficientemente contemplados na agenda dos militantes negros (pós-80) passam a ser focalizados por nossas lentes. Entre eles, temos nos debruçado sobre a questão da juventude negra em nossos centros urbanos. Atores que protagonizam na sociedade contemporânea a fragmentação e a incerteza da vida coletiva, os jovens negros (de ambos os sexos), por meio de suas expressões artístico-musicais, vêm impondo novos desafios aos movimentos negros quanto à construção de uma identidade étnica, com base nos poderosos recursos da mídia e dos complexos informacionais (GONÇALVES, 1998, p. 47-48).

Diversos movimentos culturais ${ }^{6}$ (portanto, políticos), como o HIP HOP brasileiro, as blogueiras negras, assumem a negritude como aproximação de suas raízes culturais africanas

\footnotetext{
6 Hall (2008) refere-se a alguns exemplos dessa negritude plural, de inspiração norte-americana como o Black power, a black music, jamaicana como Rastafari, em que, num contexto globalizado, as culturas se encontram e se misturam, recriando-se, hibridizam-se. Sansone (2003), analisando a cultura negra jovem e de periferia no Brasil (Rio de Janeiro, Salvador), considera que a relação entre o local e o global é complexa, como também o é a que prevalece entre a cultura jovem global e as tradições musicais locais, e que o resultado desses contatos não é fácil de prever.
} 
e tradições que colaboram para imagens positivas do povo negro, e tem efetivado alterações na sociedade, engendrando novas configurações no campo das identidades e negritudes, inclusive questionando as formas tradicionais de fazer política do movimento social negro.

O papel das mulheres nas religiões afro-brasileiras é fundante, elas atuam como guardiães da cultura religiosa dos terreiros em diferentes lugares do país. Recife possui muitas referências femininas do axé como Dona Biu, Dona Santa, Dona Badia, Dona Nise (MENEZES, 2005) e Inês Joaquina da Costa, conhecida como Tia Inês (CAMPOS, 2005) ou Ifa Tinuké, aquela que plantou o axé no terreiro de Pai Adão, Mãe Amara, que lutou junto a outras mães de Santo para a liberação do toque nos terreiros, e tantas outras que preservam tradição das religiões afro-brasileiras na cidade.

Ressaltamos que a participação do movimento das mulheres negras na luta antirracista pela promoção da igualdade racial é de grande magnitude, já referenciada por Ribeiro (2014) em sua tese sobre Políticas de Igualdade Racial no Brasil, demarca a participação do movimento negro e o movimento de mulheres negras nos processos anteriores à Constituição de 1988.

A Marcha Zumbi dos Palmares, na Conferência de Durban e os encontros de revisão dessa histórica conferência foram momentos importantes que trouxeram para a cena política as contradições resultantes das articulações de varáveis de raça, gênero e classes, mobilizando estratégias de enegrecimento das lutas das mulheres e do feminismo brasileiro feminizando as reinvindicações do movimento social negro (CARNEIRO, 2000, p.247) e intervindo na pauta internacional contra o racismo e formas correlatas de intolerâncias.

Sueli Carneiro (2000) destaca em relação às questões de raça/etnia e diversidade, na Declaração de Beijing, o artigo 32, que afirma a necessidade urgente de "intensificar os esforços para garantir o desfrute de todos os direitos humanos a todas as mulheres e meninas que enfrentam múltiplas barreiras, devido a fatores como raça, idade, origem étnica, cultural e religiosa" (CARNEIRO, 2000, p. 256).

E para realizar o acompanhamento desses avanços nos marcos legais, as mulheres negras têm investido esforços, que vão desde as constituições de redes e articulações para a efetivação dos seus direitos humanos à denúncia sistemática das violações destes.

Para Luciana Jacoud (2008), a participação social promove transparência na deliberação e visibiliza as ações, de forma a democratizar o sistema de decisões; permite 
maior expressão e visibilidade das demandas sociais, provocando um avanço da igualdade e da equidade de políticas públicas.

As mulheres negras e mulheres de terreiro, em particular, vêm se organizando em uma diversidade de redes, intercambiando lutas e experiências de vitórias e resistências, mas antes de adentrarmos na experiência de rede de mulheres de terreiro e intervenções nas políticas públicas, aportaremos no próximo ponto algumas questões sobre as conferências de políticas de igualdade racial e as religiões afro-brasileiras.

\section{Religiões afro-brasileiras e conferências de políticas públicas de promoção de igualdade racial}

Podemos afirmar que o Estado brasileiro em termos de políticas públicas, desde as legislações escravocratas (Ventre Livre, Euzébio de Queiroz, Áurea) aos Códigos Criminais (1891, 1932, 1940), manteve um viés de negatividade acerca da cultura e do povo negro na sociedade. A presença de questões relacionadas à população negra e à religiosidade afrobrasileira de forma positiva e de afirmação de direitos, no campo legal, só serão evidenciadas a partir de 1986, com a criação da Fundação Palmares, como comprova a pesquisa de Matilde Ribeiro (2014).

Os anos que sucederam a abertura política, após os vinte anos de ditadura militar, trouxeram diversos desafios para os diferentes movimentos sociais. Estabeleceu-se uma maior articulação para a construção de um processo democrático na luta pelas diretas e por uma Constituição com ampla participação popular e avanços nos direitos das chamadas minorias: indígenas, quilombolas, população negra, mulheres, crianças, pessoas com deficiências, reafirmação do estado laico, plural e o respeito às liberdades religiosas, conforme sinalizado acima. Como resultado, a Constituição de 1988 traz o viés da diversidade e avanços no campo democrático, garantia de direitos e a afirmação dos espaços de construção de políticas públicas e controle social, Oliveira (2011) contextualiza as religiões afro-brasileiras nesse momento político,

Com a democratização do país e a institucionalização de um conjunto de políticas públicas voltadas para a população negra nos últimos 20 anos, esta visão da centralidade das religiões afro-brasileiras na política antirracista no Brasil se aprofundou tanto na percepção dos adeptos quanto na dos militantes. Desconfianças foram superadas e novas alianças forjadas com base na percepção de uma história comum compartilhada pelos dois grupos. 
Atualmente, os atores religiosos afro-brasileiros estão plenamente incorporados à arena política brasileira, seja na qualidade de elemento identitário no discurso dos movimentos sociais negros; seja como sujeitos políticos autônomos dotados de uma agenda própria; seja como objeto de políticas públicas focalizadas (OLIVEIRA, 2011, p. 53).

Neste sentido, o enfrentamento ao racismo e à intolerância religiosa, a busca pelo reconhecimento enquanto religião tem envolvido, de forma mais sistemática, as religiões afro-brasileiras nos espaços de controle social e proposição de políticas públicas, com fortalecimento nesse início de século XXI. Como resultado, foram realizados avanços significativos nos marcos legais, reconhecimento de direitos, em Ações afirmativas (AA)7, inclusive demarcando transformações significativas no campo da pesquisa em Religião, como assinala Cristina Pompa,

Nos últimos anos, a questão multicultural, o debate público sobre identidade e etnicidade, o uso político de conceito de cultura têm mostrado a centralidade da religião enquanto categoria definidora de pertencimento e, portanto, de papéis, identidades, trânsitos e conflitos políticos. Os desafios trazidos pela articulação cada vez mais complexa da dimensão cultural com a política têm provocado, pois, uma guinada nos estudos sobre religião no Brasil (POMPA, 2012, p. 162).

O terceiro milênio iniciou-se com muitas conferências e avanços no campo da Promoção da Igualdade Racial e Ações Afirmativas. Em 2001, como assinalamos anteriormente, a III Conferência Mundial contra o Racismo, Discriminação Racial, Xenofobia e Intolerância Correlata, em Durban, África do Sul, que recomendava entre outras medidas, o desenvolvimento de ações afirmativas ou medidas de ação positiva, para promoverem indivíduos ou grupos vítimas de discriminação racial.

Para responder a esses compromissos, e por pressão do MSN, o governo brasileiro, em 2002 lançou o II Programa Nacional de Direitos Humanos - II PNDH, com recomendações de medidas de caráter compensatórios ${ }^{8}$ visando a eliminação da discriminação racial e a promoção da igualdade de oportunidades.

\footnotetext{
7 Políticas de ações afirmativas (AA), isto é, políticas de reparações, de reconhecimento e valorização de sua história, cultura, identidade (BRASIL, 2004).

8 A partir dessas recomendações Ministérios e Universidades públicas instituíram as quotas para o acesso de negraslos nos serviços públicos e no ensino superior (DOMINGUES, 2008), deflagrando um fervoroso debate sobre quotas raciais desde então.
} 
Em 2005. Organizou a 1ª Conferência Nacional de Igualdade Racial (Brasília, DF), com mobilização de todos os estados brasileiros e milhares de municípios. Em 2010, institui o Estatuto da Igualdade Racial, Lei 12.288/2010, depois de várias discussões e reformulações.

A conjuntura configura o desafio para um diálogo entre movimento social negro e religião afro-brasileira no campo das políticas públicas, ou seja, efetivação de direitos, a começar pela Educação, motor de transformações e de novos paradigmas para a sociedade.

O documento base da I Conferência Nacional de Promoção da Igualdade Racial, CONAPIR, destaca as religiões afro-brasileiras como depositárias primárias e continuadoras da cosmovisão africana no Brasil:

O estado brasileiro não pode desconsideraro papel histórico e a contribuição que as religiões de matriz africana tiveram na formação da identidade e costumes do povo brasileiro, proporcionados pela chegada de milhares de africanos escravizados trazidos ao país. Essa população que, no confronto com o padrão dominante aqui existente, introduz e reproduz os valores, saberes e visão de mundo africana reelaborando e sintetizando no Brasil a relação do homem com o sagrado [...]. As comunidades de terreiros constituem-se como espaços próprios mantenedores de uma perspectiva de mundo baseada em valores, símbolos e traços culturais que expressam um sistema de ideias ancestrais africanas em nosso país (BRASIL, 2005, p. 105).

Dada a importância dessa matriz religiosa para a construção da identidade nacional, e a prerrogativa brasileira de reconhecê-las como um de seus elementos constituidor, é preciso compreender as relações, controvérsias e resultados das intervenções dessa matriz religiosa no campo das políticas públicas.

A presença das religiões afro-brasileiras nas Políticas de Igualdade Racial - PPIR no Brasil Laico é um campo a ser pesquisado, como assinala Burity em relação à baixa produção científica no âmbito do ativismo social religioso no Brasil contemporâneo,

Ainda não é grande a literatura que procura dar conta dos contornos atuais desse processo no Brasil. Nela, uma dupla referência é apontada: às mudanças mais amplas, em curso na sociedade brasileira, que envolvem uma substantiva redefinição dos padrões de relação entre estado e sociedade; e a processos endógenos de questionamento da herança recebida, no que diz respeito ao discurso social da religião, bem como de crítica social a partir de uma articulação entre discursos sociais e religiosos críticos - apoiados ou intensificados pelas mudanças sociais mais amplas, mas não meramente conjunturais (BURITY, 2007, p. 32). 
Desta forma, interessa-nos o destaque que as Conferências dão à matriz religiosa afro-brasileira na identidade nacional ${ }^{9}$, ressaltando sua importância para a cultura brasileira e seus reflexos em políticas afirmativas, bem como, as dificuldades na efetivação destas pelo Estado.

As conferências de políticas públicas constituem em um mecanismo da democracia participativa, um espaço público de diálogo entre o governo e sociedade civil (povo de terreiro, grupos culturais, militantes do MSN, quilombolas...). Em todos os estados brasileiros aconteceram essas mobilizações, sendo as capitais, locais de forte aglutinação do MSN, com maior discussão para efetivas construções de planos de enfrentamento às desigualdades sociais a partir da cor/raça/etnia.

Costa, Dos Anjos e Ferreira (2014), apontam a pertinência do estudo da participação de terreiros na promoção de políticas de igualdade racial,

Para os sujeitos afro religiosos, a continuidade das tradições opera através da oralidade e símbolos, onde a identidade se forma a todo instante e constrói-se conforme as forças do local e, as interferências das tradições vão sendo "reconstruídas" dentro das comunidades, a partir de suas referências e práticas ancestrais. Assim, o conceito de cultura tradicional está diretamente ligado às culturas distintas, de outras noções de território e espaço onde o grupo social se relaciona. (COSTA; DOS ANJOS; FERREIRA, 2014, p. 4).

Todo o processo, até chegar às Conferências, constitui em momentos de encontros, de fortalecimento de identidades étnico-raciais, articulação e tessituras de estratégias para efetivação da justiça, respeito à diversidade cultural e à luta por reparação e respeito para as religiões afro-brasileiras, para o povo de terreiro.

Compreendemos, desse modo, que esse universo é complexo e funciona como delimitador de negociações e interlocuções entre a gestão pública e os terreiros, assinalando dificuldades que vão desde à implementação de políticas públicas que atinjam as comunidades de terreiro até algumas deliberações que põem em dúvida o papel da gestão de garantir à laicidade do estado frente às demandas da população de religiões afrobrasileiras, principalmente quando ameaça o espaço de legitimação do poder e direitos

\footnotetext{
9 Advinda da ideia do Estado-nação (século XIX), uma construção simbólica na busca de uma homogeneidade de narrativas ideológicas, dissolvendo a heterogeneidade das culturas populares. Dessa forma, o Estado torna-se a totalidade com transcendência e que organiza a realidade concreta e delimita os contornos da identidade nacional (ORTIZ, 2012).
} 
constituídos pela população em geral e a acusação de favorecimento de determinadas religiões em detrimento de outras.

O combate às intolerâncias tem sido um campo de militância do MSN e de afro religiosas/os, aspectos sobre os quais articulam suas energias para a denúncia, constituição de alianças com diversos sujeitos políticos e intervenções na sociedade, como possibilidades de conquistas, de respeito e mais legitimidade enquanto religião.

Atualmente, as redes sociais têm se configurado em um espaço de muitas denúncias de intolerâncias religiosas às religiões afro-brasileiras, promovendo um debate público sobre a urgência do respeito e da criminalização enquanto atos racistas. Muitas dessas agressões são realizadas pelos denominadas/os de "evangélicas/os" ou "pentecostais", como assinalou Reginaldo Prandi:

[...] há igrejas evangélicas em que $o$ ataque às religiões afro-brasileiras e a conquista de seus seguidores são práticas exercidas com regularidade e justificadas teologicamente. Por exemplo, na prática expansiva de uma das mais dinâmicas igrejas neopentecostais, fazer fechar o maior número de terreiros de umbanda e candomblé existentes na área em que se instala um novo templo é meta que o pastor tem que cumprir (PRANDI, 2004, p. 230).

A luta pelo reconhecimento enquanto religião e contra a intolerância religiosa está presente na ocupação da esfera pública dos terreiros e tradições religiosas afro-brasileiras, marcando suas lutas, resistências e reivindicações por direitos:

Por fim, foram deixados em paz pela polícia (quase sempre), mas ganharam inimigos muito mais decididos e dispostos a expulsá-los do cenário religioso, contendores que fazem da perseguição às crenças afro-brasileiras um ato de fé, o que se pode testemunhar tanto no recinto fechado dos templos como no ilimitado e público espaço da televisão e do rádio. (PRANDI, 2004, p. 229).

Essa perseguição e demonização é uma constante por parte de religiões evangélicas neopentecostais, e que consta em seus fundamentos, como constata Milene C. Santos (2012);

As crenças neopentecostais possuem três aspectos fundamentais, que se inter-relacionam e complementam: (i) a contemporaneidade da guerra espiritual entre os seguidores de Cristo (identificados aos anjos e aos evangélicos) e os adoradores do Diabo (identificados geralmente aos orixás e entidades das religiões afro-brasileiras, bem como aos candomblecistas e umbandistas); (ii) a possibilidade de os filhos de Deus gozarem, ainda nesta vida, de todos os benefícios e bênçãos que o correto pagamento dos dízimos e ofertas pode proporcionar (Teologia da prosperidade); (iii) a 
desnecessidade de sustentar os ultrapassados e estereotipados usos e costumes de santidade (SANTOS, M., 2012, p. 149).

Para Vagner Gonçalves,

O ataque às religiões afro-brasileiras, mais do que uma estratégia de proselitismo junto às populações de baixo nível socioeconômico, potencialmente consumidoras dos repertórios religiosos afro-brasileiros e neopentecostais, é conseqüência do papel que as mediações mágicas e a experiência do transe religioso ocupam na própria dinâmica do sistema neopentecostal em contato com o repertório afro-brasileiro (GONÇALVES, 2007, p. 208).

As religiões afro-brasileiras foram sempre vistas com ressalvas pela sociedade brasileira, incluindo a Igreja Católica, que só no século XX começa a rever suas posturas:

[...] houve, também, muita perseguição e demonização dos cultos africanos por parte da Igreja católica ao longo de toda a história do Brasil, sob as mais diferentes formas. Isso, no entanto, mudou fortemente a partir de meados do século $\mathrm{XX}$, sobretudo com o Concílio Vaticano II e com uma maior abertura da Igreja Católica com relação à diversidade religiosa e à liberdade de expressão religiosa. A partir de então, começou a haver um grande esforço no interior da pastoral da Igreja no sentido de valorizar e assimilar as formas religiosas africanas, como importantes valores e práticas inerentes ao povo brasileiro. Organizou-se a Pastoral do Negro (PN) e surgiu a organização dos APNs (Agentes de Pastoral Negra) (COSTA; FOLLMANN, 2013, p. 12).

Segundo esses autores, esse processo de revisão do posicionamento da Igreja católica culminou em fins dos anos 1980 com a Campanha da Fraternidade de 1988, que focava no combate ao preconceito, à discriminação racial e à valorização da cultura e religião afrobrasileira e,

Contemporaneamente $\mathrm{o}$ trabalho das pastorais do negro que se transformaram em Pastoral Afro mantém um trabalho de conscientização da situação do negro no Brasil e constituem espaços e práticas de religiosidade negra dentro da igreja católica em diferentemente do passado das irmandades podem, manifestar sua cultura e, mas desde que estes rituais não interfiram em certos aspectos da cerimônia católica romanizada, eles operam mais com o simbolismo cultural afro, sendo que, a ritualística central da missa continua intacta (COSTA; FOLLMANN, 2013, p. 12).

As religiões afro-brasileiras são religiões do presente e como tal, sofrem influências da modernidade e seus avanços tecnológicos,

Novas tradições foram reinventadas, o passado foi reinterpretado. Acreditamos que essa nova estratégia resulta num esforço de convivência, que mistura modernização e tradição. Aponta para uma atuação aberta ao intercâmbio com a sociedade como um todo. Ao mesmo tempo, 
potencializa a informatização e a comunicação eletrônica, como um canal de diálogo, democratização do conhecimento e construção de processos de incorporação de novos adeptos, a escrita e a constante reinvenção do passado (CAMPOS, 2013, p. 24).

Nos dias atuais as buscas em tecer relações de parcerias com outros grupos religiosos se ampliaram, socializando informações sobre o funcionamento dos terreiros, na tentativa de desconstruir preconceitos, o uso das redes sociais e os mais variados espaços públicos para denúncia de intolerâncias e proposição de diálogos inter-religiosos, tanto por quem pratica a religião, como para quem defende o direito à liberdade religiosa.

Parte dessa luta está a busca pelo reconhecimento das religiões afro-brasileiras enquanto religiões no mesmo nível das demais e os terreiros como espaço de memória e ancestralidade (patrimonialização, tombamentos ${ }^{10}$ ), como corroboram estudos acerca dessa questão (GIUMBELLI, 2008; MORAIS, 2012; LIMA, 2014). Dessa forma, os tombamentos de terreiros se configuram na identificação destes como espaços "culturais" o que envolveu todo processo de análise e fundamentação antropológica, sendo assim, a inclusão da religião a título de cultura, e que fosse assim concebida e considerada, respondendo a histórica demanda por respeito a essa matriz religiosa.

Para Oliveira (2011), as deliberações da I CONAPIR indicam uma ambiguidade de reivindicações para o campo religioso afro-brasileiro, em que, ora se apresenta como necessidade de um tratamento diferenciado (abordagem diferencialista) ora demanda por um tratamento igualitário (abordagem universalista):

Há enfim, ao longo do texto uma tensão entre esses dois movimentos: a reivindicação por um tratamento diferenciado - em função da contribuição para a formação da identidade nacional, da história de perseguições sofridas e da especificidade dos valores que caracterizam essas tradições; e de outro a demanda por um tratamento igualitário caracterizado pelo acesso aos direitos concedidos às demais denominações (aposentadoria; isenção de IPTU; reconhecimento civil do casamento religioso; capelania, etc (OLIVEIRA, 2011, p. 59)).

Essas duas abordagens são verificadas também nas propostas apresentadas pelo povo de terreiro em Recife e em ações apresentadas nas gestões de igualdade racial.

\footnotetext{
${ }^{10}$ Com a criação do Registro de Bens Culturais de Natureza Imaterial, em 2000, as concepções de patrimônio e de preservação passam a considerar a valorização de diferentes formas de realização cultural como bens a serem preservados, até meados dos anos 1970, apenas era dada proteção física de bens culturais, muito aos modelos artísticos e estéticos europeus (LIMA, 2014).
} 


\section{Recife e as políticas de igualdade racial: reconhecimento da luta do MSN e das religiões afro-brasileiras}

No Município de Recife, a promoção da igualdade racial está inserida na área dos direitos humanos e segurança cidadã e teve como órgão gestor, nos anos de 2005 a 2012, a Diretoria da Igualdade Racial, responsável pela Política de Promoção da Igualdade Racial. Esta foi instituída pela Lei 17.108/05, com o objetivo político definido de: "Coordenar e articular Políticas de Promoção da Igualdade Racial, qualificando e ampliando o debate sobre ações afirmativas de forma transversal e intersetorial, articulada com a sociedade civil" (Lei 17.108/05).

A Prefeitura do Recife no período de gestão do Partido dos Trabalhadores (PT- 2001 a 2012)11, adotou a abordagem multicultural em suas ações, com valorização das manifestações culturais plurais, com grande foco nas afro-brasileiras, em seus aspectos artísticos, porém destituídos dos aspectos religiosos (BURITY, 2007). Segundo o autor essa postura advém do laicismo implícito nas políticas municipais:

De um lado, para tomar um exemplo, incorporam-se no Multicultural as expressões religiosas afro-brasileiras; mas estas são despidas de seu caráter religioso, tornando-se elementos culturais inseparáveis da identidade negra e africana (o que não apenas invisibiliza a diferença religiosa, como uniformiza e essencializa o que supostamente seria a experiência da religião na África) (BURITY, 2007, p. 41).

Esse posicionamento, por sua vez, pode inviabilizar uma discussão mais profunda sobre as políticas afirmativas, como estratégia de redução das desigualdades étnico-raciais e o lugar das religiões afro-brasileiras na esfera pública, podendo gerar uma visão utilitarista de grupos culturais, sem demarcação de uma discussão dessas religiões enquanto conhecimento e saberes ancestrais. Porém, isso não significa que a experiência religiosa não possa se completar com outros rituais tomados como bens culturais, beneficiados com recursos públicos, isso se dá de forma bastante comum com as organizações culturais de maracatus e afoxés no Recife, que têm os terreiros como nascedouro e espaço de fortalecimento.

\footnotetext{
${ }^{11}$ Este período se refere a três (03) gestões do PT iniciada 2001-2004; 2005-2008; 2009-2012. Percebemos que mesmo antes da implantação de uma diretoria específica para questões étnico-raciais já havia ações e atividades abordando a população negra e algumas de suas especificidades.
} 
Burity (2007) alerta para essa relação entre religião e política tão presente na contemporaneidade e que, de forma alguma, foge às disputas de poder e de projeto de sociedade.

Emerson Giumbelli (2008, p. 86) atento para o fato de que "a referência às minorias étnicas como base para "políticas de reconhecimento" é outro ponto sujeito a debate, pois ele não estava presente nas formulações clássicas acerca da "liberdade religiosa" e, ao mesmo tempo não ser possível questionar o espaço público sem um olhar atento acerca dos espaços ocupados pelos grupos sociais que nele atuam. Para o autor, isso coloca em permanente jogo o papel e a constituição do Estado.

O reconhecimento em relação à luta do movimento negro nesse processo de reivindicação do lugar da população negra, é visível já no documento base da Conferência Nacional de Promoção da Igualdade Racial e no caderno de propostas da I CMPPIR de Recife:

A $1^{\text {a }}$ CONFERÊNCIA MUNICIPAL DE PROMOÇÃO DA IGUALDADE RACIAL DO RECIFE é uma resposta da administração municipal aos anseios históricos do Movimento Negro pernambucano, em especial, do Recife, que sempre buscou, de forma incessante, romper as barreiras do preconceito fundado no critério de raça/cor, do racismo e da discriminação racial, para forjar uma sociedade justa, onde todos pudessem viver em harmonia e a descendência africana não constituísse barreiras para o livre exercício da cidadania do brasileiro (RECIFE, 2005, p. 15).

O documento citado reconhece a importância da conferência para o estabelecimento de todas as partes envolvidas para a discussão do tema e como um momento privilegiado de debate com o poder público em assumir o compromisso público para a superação das desigualdades raciais e a promoção da igualdade.

Oliveira (2011) ao analisar os documentos da I e II Conferências Nacional aponta o termo matriz africana como escolha de concepção, segundo essa autora, a expressão "de matriz africana" parece buscar enfatizar a ideia de uma vinculação direta entre a origem (matriz) e a contemporaneidade dessas religiões, por isso a ausência do uso afro-brasileira nos documentos da I CONAPIR.

Várias observações que foram realizadas pela autora, também se apresentam nos documentos da I CMPPIR Recife, inclusive em relação a ausência de outras denominações religiosas ou outros grupos étnicos, como ciganos nas propostas, o que vai se diferenciar na II CONAPIR. Em Recife, a ausência permanece nas deliberações de todas as Conferências realizadas. 
Das proposições da I Conferência do Recife em 2005, no grupo sobre Religiões, a maioria se repete nas conferências subsequentes principalmente quanto à defesa e conservação do patrimônio, equiparação do status das outras religiões e isenção de IPTU para os terreiros, construção dos memoriais de Oxum e lemanjá, articular ações da saúde com os terreiros, enfrentamento à intolerância religiosa e informações sobre os cultos afrobrasileiros para a diminuição dos preconceitos, a partir da Lei 10.639/03, como consta nos resultados da III conferência:

1. O Município deve reconhecer a importância das religiões de matriz africana, objetivando a valorização, preservação, guarda e defesa do patrimônio cultural afro-descendente nos seus aspectos material e imaterial. Preservar e proteger os cultos das religiões de matriz africana e garantir a preservação dos territórios patrimoniais da população negra, para que seus conhecimentos milenares sejam resguardados

2. Promover no município do Recife o mapeamento das casas religiosas de matriz africana, assegurando o acesso às informações produzidas por este mapeamento.

3. Promover no município o tombamento das casas religiosas de matriz africana, classificadas de acordo com o tempo de existência, a partir de critérios estabelecidos com a comunidade, objetivando a guarda e proteção da territorialidade cultural destas religiões.

4. Adequar a lei de isenção do IPTU para os llês (Casas de Religiões de Matriz Africana), também promover a discussão da lei 10.639/03 em função das especificidades dos cultos de matriz africana (CMPPIR, 2007).

Um dos problemas apresentado na nossa pesquisa e que rebate na concretização das políticas públicas para o terreiro é que algumas ações não estão no campo de política de Estado, mas de governo, e de uma vinculação com a escolha partidária da liderança, nesse sentido, há implicação direta, visto não haver um plano de execução das deliberações das conferências e o recurso orçamentário para sua execução.

O princípio da laicidade vem sendo utilizado como discurso de negação ao direito constituído legalmente, quando são feitos questionamentos sobre as leis em conexão direta com as religiões afro-brasileiras, e no silêncio de sua implementação inconclusa.

A estratégia adotada pela gestão 2005/2012 foi o envolvimento dos terreiros, dentro de políticas que valorizam as tradições culturais de matrizes africanas e afro-brasileiras, terreiro como parte da cultura e resistência negra, presente nas propostas de ações, como enfatiza: 
Tanto é que no caso da Prefeitura do Recife a gente começou essa relação a partir da cultura, não foi a partir de um coletivo de religiosos, de uma discussão sobre a coisa da religião, entendeu, da fé, nada disso, e o que foi colocado foi a partir da manutenção de uma tradição de matriz africana através do terreiro a gente se preserva e era preciso preservar o terreiro, pra poder a gente se conhecer e dar continuidade a tudo que os povos africanos trouxeram para o Brasil, então o terreiro é uma forma de continuidade de uma tradição de alguns povos...e tal. (Gestão PT, 2016, informação verbal).

A gestão 2013-2016 também pontuou este fato como empecilho para a viabilidade da implementação dessas políticas, deliberadas reiteradamente nas três (03) conferências.

Ao assumir o discurso dos terreiros como espaço de acolhimento, cultura e ancestralidade, as gestões de políticas de igualdade racial reafirmam a necessidade de articular o que já prevê a Constituição Brasileira (1988) em relação à liberdade religiosa, aliado a todos os acordos internacionais quanto à promoção de ações afirmativas que visem diminuir o fosso das desigualdades sociais herdadas pelo seu passado escravocrata, pois:

Qualquer experiência fenomenológica é capaz de atestar a força do racismo na sociedade brasileira contemporânea, experiência esta que se confirma a cada dado estatístico referente à enorme desvantagem dos negros no que tange à sua posição socioeconômica, bem como ao seu acesso à educação, saúde, emprego etc. Trata-se de uma ordem racista pautada na ideia de que as pessoas com uma determinada aparência, fenótipo, ou "herança genética", são naturalmente inferiores (TAVOLARO, 2010, p. 295).

Essa urgência de enfrentamento ao racismo e à intolerância religiosa ${ }^{12}$ foi identificada nas entrevistas e também nas propostas resultantes das Conferências de Igualdade Racial, principalmente nas questões que se referem às proposições sobre educação das relações étnico-raciais, mas, precisamente, referente à implementação da legislação sobre História e Cultura africana, afro-brasileira e Indígena - Leis 10.639/03 e 11.645/0813.

O viés culturalista (GIUMBELLI, 2008) é mais aceito dentro da perspectiva histórica de "participação do povo africano na formação da nação" do que o reconhecimento da necessária reparação histórica dos processos de escravização e da abolição inconclusa, como da perseguição às religiões afro-brasileiras, bem como há a dificuldade em afirmar-se como ritos religiosos, no campo da esfera pública.

\footnotetext{
${ }^{12}$ A ideia de racismo como uma especificidade da intolerância praticada contra as religiões afro-brasileiras está presente no texto da II CONAPIR (p. 58). Na primeira CMPPIR Recife foram og propostas que tratam da necessidade de combater a intolerância religiosa e os estereótipos em relação às religiões afro-brasileiras, seja através de campanhas, cartilhas, formações, assessorias jurídicas para as vítimas, e até de punições para agentes públicos que pratiquem atos abusivos nos terreiros.

${ }^{13}$ Recordando: Legislação que modifica a Lei de Diretrizes e Bases da Educação e que torna obrigatório o ensino de História e Cultura Africana, Afro-brasileira e Indígena.
} 
A aceitação enquanto imagem relacionada ao carnaval e em imagens turísticas (GONZALEZ, 1988) é continuadamente reiterada, configura-se na folclorização das religiões afro-brasileiras e numa efetiva dificuldade de inseri-las num contexto mais amplo, como na educação.

Dessa forma, a participação dos terreiros nas esferas públicas, reafirmando demandas enquanto territórios religiosos. exige uma perspectiva diferente nas políticas públicas, cuja compreensão, desse campo de disputa, vai variar, de acordo com as possibilidades de reflexões e formação política de seus participantes.

A partir dessa premissa, o entendimento sobre políticas públicas muitas vezes se restringe às questões relacionadas à liberdade de culto e à relação com os direitos dos outros, também com a interferência do poder público em delimitar esse direito, principalmente quando são pessoas de grupos com direitos limitados quanto às políticas de igualdade racial e religiosa.

A relação com políticos e pessoas influentes apresenta-se de forma diversa, muito antes dos processos de conferências, mas com interferência direta em relação à visibilidade e ao respeito, como no exercício de culto (MENEZES, 2005; MORAIS, 2012; GUILLEN, 2007

A ausência de um Plano Municipal de Igualdade Racial para implementação dessas políticas, que definiria recursos orçamentários e o compromisso público da gestão, pode representar esse descompromisso das gestões de dar continuidade ao que deveria ser política de Estado.

Na educação do Recife a atuação do GTERÊ foi abordada por Claudilene Silva (2009) e por Elizama Messias (2010) e apontam que as ações se caracterizam como de caráter pontual, não atingindo os processos de formação continuada da maioria de professoras/es, sem contemplar os níveis da educação básica e sem a devida incorporação ao projeto político pedagógico da Rede de Ensino, com ausência de metas e recursos próprios, sendo as ações de formação financiadas por agentes externos, a partir do PCRI/DFID.

Nesses processos que caracterizaram a construção e realização das Conferências, bem como, na ausência de implementação da maioria de suas deliberações, tem-se evidenciado a complexidade de se efetivar a igualdade racial, no sentido de acesso aos direitos, serviços e ações do Estado, contemplando a diversidade identitária e a universalização da pessoa. Dessa forma, acreditamos que o controle social é um aspecto a 
ser priorizado, abordaremos a seguir a experiência da Rede de Mulheres de Terreiro de Pernambuco nesse espaço de monitoramento de políticas públicas.

\section{Rede de mulheres de terreiro: o controle social com as mulheres do axé}

Desde 2007, a Rede de Mulheres de Terreiro ${ }^{14}$ se configura como referência por suas contribuições, tanto para o fortalecimento das mulheres dessa matriz religiosa, quanto para o controle social, ou seja, num movimento para dentro e outro para fora: visibilidade, respeito às religiões afro-brasileiras e combate ao racismo/intolerância religiosa e monitoramento de políticas públicas com recorte de gênero e étnico-racial, tem merecido espaço nesse estudo por fazer ações de controle social das políticas de promoção da igualdade racial.

Meira (2014) resume a forma organização da Rede:

A Rede das Mulheres de Terreiro de Pernambuco não é uma organização não governamental. Ela não possui personalidade jurídica e também não gera vínculos empregatícios. Todas as formas de participação são voluntárias. A Rede é uma articulação de terreiros de várias denominações dos cultos afrobrasileiros e indígenas, 51 existente em Pernambuco, 21 representados pelas mulheres, é um grupo que se reúne para discutir temas que lhes são pertinentes e que demandam atividades políticas, sociais, mas também religiosas. [...].De acordo com o relato das mulheres, há duas instâncias oficiais, que é a Coordenação Colegiada, e o Conselho Religioso (MEIRA, 2014, p. 50-51).

A Rede de Mulheres de Terreiro tem realizado ações de controle social e apresentado ao Ministério Público de Pernambuco denúncias de violações de direitos humanos e de intolerância religiosa, um papel fundamental para o monitoramento de políticas públicas implementadas e pautando sua avaliação:

[...] enfim, nós passamos a ser também um dos sujeitos políticos a, vamos dizer, a efetivar as políticas públicas, trazendo ideias também, foi muito importante e, sobretudo, combatendo o racismo, o preconceito e a violência, preconceito contra a nossa forma de crença e culto, o preconceito sobre a nossa identidade de gênero, e o preconceito, a discriminação, o racismo contra a nossa identidade racial e religiosa, então por conta disso, aconteceram várias coisas, nós passamos a estar muito mais próximas ao Ministério Público, exigindo que ele cumprisse o seu papel, porque ele é um instrumento de preservação do estado democrático de direito, da democracia, não é? Da efetivação das leis, dos

\footnotetext{
${ }^{14} \mathrm{O}$ primeiro encontro de mulheres de terreiro de Pernambuco: apejó Ikini Obirin N'llê foi realizado nos dias 26 e 27 de julho de 2007, por iniciativa do terreiro de Mãe Amara llê Obá Aganjú Okoloyá em parceria com a Uiala Mukaji sociedade das mulheres negras de PE, o objetivo foi partilhar o conhecimento ancestral, fortificar a identidade de mulheres de terreiro como sujeito político, lideranças e protagonistas sociais, além de identificar as suas principais demandas (MEIRA, BARONI, 2010, p. 11).
} 
cumprimentos das leis, não é? E também da garantia de nossos direitos indisponíveis. (Vera Baroni, entrevista ,2016, informação verbal).

Para Vera Baroni (entrevista, 2016), o controle social ${ }^{15}$ é exercido de várias maneiras, mas formalmente, a partir da constituição dos conselhos da política, seja da educação, da saúde, da mulher, da igualdade racial, e também dos processos das Conferências, que é o momento onde se analisa e aprimora a política.

O conceito de controle social é bem abrangente, pode ser feito através de avaliações nas ouvidorias, nos conselhos gestor de unidade de saúde, nas denúncias ao MPPE, em entrevistas para os meios de comunicação e nas redes sociais, portanto, ao exercer o monitoramento das políticas públicas, a Rede de Mulheres de Terreiro colabora nesse processo de diálogo entre as deliberações das conferências e a efetivação destas pelo poder público, mesmo estando fora dos conselhos, como pressuposto de que "as/os cidadãs/ãos têm a responsabilidade e o direito de intervir e controlar a ação do Estado", destaca CARNEIRO (2000, p. 253), sobre os processos para a Conferência de Beijing pós-intervenção das mulheres negras.

A Rede de Mulheres de Terreiro de Pernambuco vem reafirmando essa premissa, e engendra esforços para acompanhar e monitorar algumas políticas de igualdade racial em Pernambuco, com olhar interseccional, tendo como aporte as deliberações das conferências e os acordos internacionais dos quais o Brasil é signatário, bem como a Constituição Brasileira de 1988, que já prevê no âmbito da participação relativa aos direitos sociais, à proteção social e a democratização das instituições.

\section{Considerações finais}

Percebemos nesse resgate das memórias do MSN que a proposta de uma educação antirracista faz parte de suas reivindicações históricas, a relação com as Religiões afrobrasileiras foi incorporada na luta por reconhecimento e por políticas públicas, e se fortaleceu nos espaços das conferências de igualdade racial, direcionado para o enfrentamento às intolerâncias religiosas a partir de ações educativas e pela implementação da Lei 10.639/03.

\footnotetext{
${ }^{15}$ Segundo o portal da transparência (BRASIL), a ideia de participação e de controle social estão intimamente relacionadas, se dá através da participação na gestão pública, onde cidadãs e cidadãos podem intervir na tomada da decisão administrativa, de forma a orientar a gestão na adoção de medidas que venham a atender o interesse público, bem como, exercer controle sobre a ação do Estado, exigindo que este, atue com transparência.
} 
As Políticas Públicas de Igualdade Racial, tendo as ações afirmativas como estratégias $^{16}$, foram analisadas por Matilde Ribeiro, (2014) e Silva Jr., Bento e Silva (2010) e mostram que os avanços, em termos de legislação e na colocação da pauta negra nas políticas de Estado, são bastante relevantes, mas o processo de implementação dessas ações, com modificações no cotidiano das populações, ainda necessita de um tempo histórico no processo de transformação cultural e redução das desigualdades sociais geradas pelo racismo e sexismo estruturadores da sociedade brasileira.

Desde os anos 2000, a perspectiva dos movimentos sociais assume um caráter crítico, com ganhos de participação nos espaços públicos e negociação nos espaços governamentais e estatais, já instalado nos anos $1990^{17}$. Todavia, essas iniciativas não garantiram transformações efetivas nas vidas de cidadãos e cidadãs brasileiras, sendo necessária capacitar essa participação e fortalecer a sociedade civil organizada, desde o movimento de base, e a organização de grandes mobilizações de massa e de parcerias para implementação de políticas sociais e públicas.

Para transformar as relações desiguais pautadas no racismo, que atinge de forma específica mulheres e o povo de terreiro, é necessário questionar o Estado quanto ao acesso aos bens sociais, culturais pela população negra, bem como sobre suas ações de combate ao racismo institucional, visando o cumprimento de compromissos internacionais assumidos:

Contudo, dado os fatores históricos e os constrangimentos raciais que ainda hoje operam no país, as políticas universais têm se revelado insuficientes face ao objetivo de enfrentar a discriminação e desigualdade racial. A presença do racismo, do preconceito e da discriminação racial como práticas sociais, aliadas à existência do racismo institucional, representa um obstáculo à redução daquelas desigualdades, obstáculo este que só poderá ser vencido com a mobilização de esforços de cunho específico. Assim, a implementação de políticas públicas específicas, capazes de dar respostas mais eficientes frente ao grave quadro de desigualdades raciais existente em nossa sociedade, apresenta-se como uma exigência incontornável na construção de um país com maior justiça social (JACCOUD, 2008, p. 137).

\footnotetext{
${ }^{16}$ Matilde Ribeiro (2014, p. 241) elenca como partes dessas ações afirmativas: O Plano Plurianual - PPA - como instrumento de planejamento e diretriz orçamentária; a SEPPIR - Secretara de Promoção da Igualdade Racial - como estrutura; a Política e o Plano Nacional de Promoção da Igualde Racial, como mecanismo de definição de diretrizes e monitoramento; o Fórum Intergovernamental de Políticas de Promoção de Igualdade Racial estratégia de capilaridade e federalização das políticas; o Conselho Nacional de Igualdade Racial e a Conferência de Nacional Igualdade Racial - CONAPIR - como expressão de democratização da gestão; e o Estatuto da Igualdade Racial, como referência legal.

17 Recordamos que a Marcha Zumbi, 1995, teve como um dos resultados a criação de um GT interministerial para discussão sobre políticas de igualdade racial.
} 
Dessa forma, enquanto as políticas universalistas não garantirem o acesso em igualdade, o pressuposto é que as políticas afirmativas assumam esse lugar.

As dificuldades de acompanhamento da implementação das políticas de igualdade racial propostas em conferências, especialmente da legislação específica na educação, requer ações de monitoramento do movimento social negro e dos terreiros, a Rede de Mulheres de Terreiro de Pernambuco tem pautado essa luta e também a necessária interseccionalidade das questões de gênero, racial e religiosa no debate sobre igualdade racial, tão indispensável para a efetivação de direitos.

A rede de mulheres de terreiro no controle social tem pautado o Ministério Público de Pernambuco para o debate em audiências públicas exigindo ações do Estado e Municípios para o enfrentamento à intolerância e pela implementação da Lei 10.639/03, discutido com a gestão pública acerca da institucionalização dos terreiros, isenção de taxas, espaço para oferendas e outras demandas específicas (MEIRA, 2014, p. 44-45), além da articulação com o movimento social negro, de mulheres negras e feministas, em âmbito nacional e local.

Pontuamos esse novo movimento social, (mulheres negras e mulheres de terreiro, por exemplo) como movimento cidadão crítico, que "se constitui em torno de uma identidade ou identificação coletiva, da definição de adversários ou de conflito e de um projeto de mudança social ou utópica num contínuo processo em construção" (SCHERER-WARREN, 2008, p. 16). Mas, sabemos que, na esfera estatal, os jogos de poder nem sempre são favoráveis para a efetivação da cidadania de forma igualitária para todas as pessoas.

\section{Referências}

BATISTA, Maria de Fátima Oliveira. Contribuição do movimento negro de Pernambuco na construção da Lei 10.639/03. In SANTIAGO, Eliete; SILVA, Delma; SILVA, Claudilene. (Orgs.). Educação, escolarização \&identidade negra: 10 anos de pesquisa sobre relações raciais no PPGE/UFPE. Recife: Editora Universitária, UFPE, 2010.

BRASIL. CNE -Conselho Nacional de Educação/Conselho Pleno/DF. Diretrizes Curriculares Nacionais para a Educação das Relações Étnico-Raciais e para o Ensino de História e Cultura Afro-Brasileira e Africana. 23001.000215/2002-96 CNE/CP 3/2004, aprovado em 10 mar. 2004. . Constituição da República Federativa do Brasil de 1988. Disponível em: <http://www.planalto.gov.br/ccivil_03/constituicao/constituicao.htm>. Acesso em: 15 jan. 2016. . Ministério da Educação. Secretaria da Educação Continuada, Alfabetização e Diversidade. Diretrizes Curriculares nacionais para a Educação das relações Étnico-Raciais e para o Ensino de história e Cultura Afro-Brasileira e Africana. Brasília: SECAD, 2005. 
Portal da Transparência. [S. I, s.d]. Disponível em:

<http://www.portaldatransparencia.gov.br/controlesocial>. Acesso em: 03 out. 2016.

Mapeando o Axé. Pesquisa socioeconômica e cultural das comunidades tradicionais de terreiro. Disponível em: <http://www.mapeandoaxe.org.br/terreiros/recife>. Acesso em: 24 jan. 2016.

Ministério do Desenvolvimento e Combate à fome. Alimento: direito sagrado - pesquisa socioeconômica e cultural de povos e comunidades tradicionais de terreiros. Brasília, DF: MDS, Secretaria de avaliação e Gestão da informação, 2011. Disponível em:

<http://www.brasil.gov.br/cultura/2011/11/pesquisa-identifica-mais-4-mil-terreiros-em-apenasquatro-cidades-do-pais $\geq$. Acesso em: 01 out. 2016.

BURITY, Joanildo. Organizações religiosas e ações sociais: Entre as políticas públicas e a sociedade civil. Revista Anthropológicas. Recife, v.18, n. 2, p.7-48, 2007.

. Religião, política e cultura. Tempo Social - Revista de Sociologia da USP. São Paulo, v. 20, n. 2 , p. 83-113, nov. 2008

CAMPOS, Zuleica Dantas Pereira. De xangô a candomblé: transformações no mundo afropernambucano. Horizonte. Belo Horizonte, v.11, n.29, p.13-28, jan./mar., 2013.

CARNEIRO, Sueli. Raça e etnia no contexto da Conferência de Beijing. In: WERNECK, jurema; MENDONÇA, Maisa; WHITE, Evelyn C. O livro da saúde das Mulheres Negras: nossos passos vêm de longe. Rio de Janeiro: Pallas; Criola, 2000.

A organização nacional das mulheres negras e as perspectivas políticas. Revista de Cultura Vozes. Florianópolis, v. 84, n. 2, p. 211-219, mar./abr.1990.

CONFERÊNCIA NACIONAL DE PROMOÇÃO DA IGUALDADE RACIAL. Conapir. Brasília: Seppir. Relatório Final. 2006. Disponível em:

<http://www.planalto.gov.br/seppir/publicações/relatorio_final_conapir>. Acesso em: 3 nov. 2016.

COSTA, Renilda Aparecida. Religião de matriz africana em Lages (SC): espaços e práticas de reconhecimento identidade étnicorracial. 2011. 186 f. Tese (Doutorado em Ciências Sociais) Programa de Pós-Graduação em Ciências Sociais, Universidade do Vale do Rio dos Sinos, São Leopoldo-RS, 2011.

COSTA, Renilda Aparecida; FOLLMANN, José Ivo. Processos de construção da identidade nacional brasileira: velhas e novas interrogações sobre a contribuição das religiões de matriz africana. 2013. Disponivel em: < http://www.dhi.uem.br/gtreligiao/anais4/8.pdf>. Acesso em: 06 jan. 2015.

CRENSHAW, Kimberle. Documento para o encontro de especialistas em aspectos da discriminação racial relativos ao gênero. Estudos Feministas. Florianópolis, v.10, n.1, p. 171-188, 2002.

DOMINGUES, Petrônio. Movimento Negro Brasileiro: alguns apontamentos históricos. Tempo, Niterói, n. 23, p. 2007, p. 100-122.

A nova abolição. São Paulo: Selo Negro, 2008.

GIUMBELLI, Emerson. A presença do Religioso no espaço público: modalidades no Brasil. Religião e Sociedade, Rio de Janeiro, n. 2, p. 80-101, 2008. 
. O fim da religião: dilemas da liberdade religiosa no Brasil e na França. São Paulo: Attar Editorial, 2002.

GONÇALVES, Luiz Alberto de Oliveira. Os movimentos negros no Brasil: Construindo atores sociopolíticos. Revista Brasileira de Educação, Belo Horizonte. n. 9, set./out./nov./dez., 1998.

GONÇALVES, Luiz Alberto de Oliveira; SILVA, Petronilha Beatriz Gonçalves e. Movimento negro e educação. Revista Brasileira de Educação, Belo Horizonte, n. 15, p. 134-158, set./dez. 2000.

GONZALEZ, Lélia. As amefricanas do Brasil e sua militância. Jornal Maioria Falante, n. 7, mai./jun., 1988

Lélia fala de Lélia. Rio de Janeiro: Estudos Feministas. Florianópolis, n. 2, p.383-386, 1994.

GELEDÉS. Racismo Institucional: uma abordagem conceitual. Disponível em:<

http://www.onumulheres.org.br/wp-content/uploads/2016/04/FINAL-WEB-Racismo-Institucionaluma-abordagem-conceitual.pdf >. Acesso em: 19 mai. 2017.

GUILLEN, Isabel Cristina Martins. Catimbó: saberes e práticas em circulação no Nordeste dos anos 1930-1940. In LIMA, Ivaldo Marciano de França; GUILLEN, Isabel Cristina Martins. Cultura afrodescendente no Recife: Maracatus, valentes e catimbós. Recife: Edições Bagaço, 2007.

HALL, Stuart. Da Diáspora: identidades e mediações culturais. Trad: Adelaine La Guardia Resende et all. Belo Horizonte: Editora UFMG, 2008.

IBGE. População do Recife. Disponível em:<http://cidades.ibge.gov.br/\. Acesso em: o1 out. 2016.

JACCOUD, Luciana. O combate ao racismo e à desigualdade: o desafio das políticas públicas de promoção da igualdade racial. In: THEODORO, Mário. (Org.). As políticas públicas e a desigualdade racial no Brasil: 120 anos após a abolição. Brasília: Ipea, 2008.

LIMA, Alexandra Rodrigues. Reconhecimento do Patrimônio Cultural Afro-brasileiro. Revista Palmares, Brasília, n. 8, p. 6-15, nov. 2014.

LIMA, Ivaldo Marciano de França. Maracatus-nação: ressignificando velhas histórias. Recife: Edições Bagaço, 2005.

LIMA, Ivan Costa; ANJOS, Raiane Mineiro dos; FERREIRA; Deyziane. As lutas por direitos das comunidades tradicionais de terreiros pela igualdade racial no sul e sudeste do Pará. II Congresso Nacional Africanidades e Brasilidades, Espírito Santo, 2014.

MARCHA ZUMBI DOS PALMARES. Documentário. Disponível em: <http://www.geledes.org.br/marcha-zumbi-dos-palmares-1995/\#gs.jdc5QjY >. Acesso em: 23 jan. 2016.

MEIRA, Fernanda; BARONI, Vera. Obirin N'Ilê: a expressão coletiva de nossas necessidades. Recife: ISBA-Instituto Social Brasil África, 2010.

Afirmação da Identidade Religiosa e constituição do sujeito político das Mulheres de Terreiro de Pernambuco, Dissertação - Programa de Pós-Graduação em Antropologia - UFPE, Recife, 2014

MENEZES, Lia. As Yalorixás do Recife. Recife: Funcultura, 2005. 
MESSIAS, Elizama Pereira. A implantação das políticas educacionais de promoção da igualdade racial na cidade do Recife. In SANTIAGO, Eliete; SILVA, Delma; SILVA, Claudilene. (Orgs.).

Educação, escolarização \& identidade negra: 10 anos de pesquisa sobre relações raciais no PPGE/UFPE. Recife: Editora Universitária, UFPE, 2010.

MORAIS, Mariana Ramos de. Políticas Públicas e a fé afro-brasileira: uma reflexão sobre ações de um Estado laico. Ciencias Sociales y Religión/Ciências Sociais e Religião, Porto Alegre, n. 16, p. 3959. jan./jun., 2012.

OLIVEIRA, Rosalira Santos. Guardiãs da identidade? As religiões afro brasileiras sob a ótica do movimento negro. Magistro - Revista do Programa de Pós-Graduação em Letras e Ciências Humanas-UNIGRANRIO, v. 2, n.1, p. 50-68, 2011.

ORTIZ, Renato. Cultura brasileira e identidade nacional. 5 ed. São Paulo: Brasiliense, 2012.

POMPA, Cristina. Introdução ao dossiê religião e espaço público: repensando conceitos e contextos. Religião e Sociedade, Rio de Janeiro, v. 32, n. 1, p. 157-166, 2012.

PRANDI, Reginaldo. O Brasil com axé: Candomblé e Umbanda no mercado religioso. Estudos Avançados, São Paulo, n. 52, p.223-238, 2004.

As religiões afro-brasileiras e seus seguidores. Civitas-Revista de Ciências Sociais v. 3, n. 1, p.15-33, jun., 2003.

RECIFE. $1^{\text {a }}$ Conferência Municipal de Promoção da Igualdade Racial: Caderno de Propostas, Recife, 2005. (Impresso)

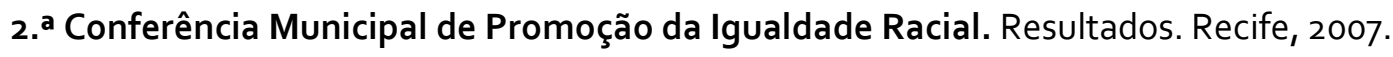

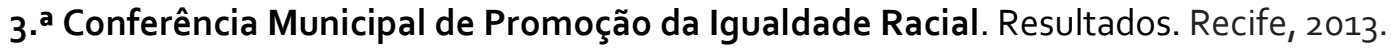

Políticas de promoção da igualdade racial do Recife. Banco de Buenas Prácticas, 2011a.

Disponível em: <

http://www.bancodebuenaspracticas.org/_files/proyectos/121da_POL\%C3\%8DTICAS\%20DE\%2oP ROMO\%C3\%87\%C3\%83O\%20DA\%2olGUALDADE\%20RACIAL\%20DO\%20RECIFE.docx>Acesso em: 18 de set. 2016. Já não consta em 2017.

Projeto de Fortalecimento Institucional. Banco de Buenas Prácticas, 2011b. Disponível em: $<$ http://www.bancodebuenaspracticas.org/proyecto.php?idp=125>. Acesso em: 10 mai. 2017.

Relatório 2013-2016. Gerência de Igualdade Racial do Recife. Recife promovendo, debatendo e difundindo a Promoção da Igualdade Racial. Recife, dez. 2016.

SEPPIR. Plano nacional de desenvolvimento sustentável dos povos e comunidades tradicionais de matriz africana. Brasília: Secretaria de Políticas de Promoção da Igualdade Racial, 2013.

Relatório Final I Conferência Nacional de Promoção da Igualdade Racial: Brasília, 30 de junho a 2 de julho de 2005. Brasília: Secretaria Especial de Políticas de Promoção da Igualdade Racial, 2005.

RIBEIRO, Matilde. Políticas de promoção da igualdade racial no Brasil: 1986-2010. Rio de Janeiro: Garamond, 2014. 
SALES Jr., Ronaldo. Políticas de Ancestralidade: negritude e africanidade na esfera pública. Caos Revista Eletrônica de Ciências Sociais, João Pessoa, n. 14, p 119- 133, set. 2009.

SANSONE, Lívio. Negritude sem etnicidade: o local e o global nas relações raciais e na produção cultural negra do Brasil. Tradução: Vera Ribeiro. Salvador: Edufba; Pallas, 2003.

SANTOS, Joel Rufino dos; BARBOSA, Wilson do Nascimento. Movimento negro e crise brasileira, Atrás do muro da noite; dinâmica das culturas afro-brasileiras. Brasília: Ministério da Cultura/Fundação Cultural Palmares, 1994.

SANTOS, Milene Cristina. O Proselitismo religioso entre a Liberdade de expressão e o Discurso de ódio: a "Guerra santa" do Neopentecostalismo contra as Religiões afro-brasileiras. 2012. $245 \mathrm{f}$. Dissertação (Mestrado em Direito, Estado e Constituição) - Faculdade de Direito, Universidade de Brasília, Brasília, 2012.

SCHERER-WARREN, Ilse. Das ações coletivas às redes de movimentos sociais, 2008.

Movimentos em cena: ... e as teorias por onde andam? Revista Brasileira de Educação, Belo Horizonte, n. 9, p. 16-29, set/out/nov/dez, 1998.

SILVA, Claudilene. A Questão Étnico-Racial na Sala de Aula. Brasília: ANPED, 2006. Relatório de Pesquisa.

O Processo de Implementação da Lei No 10.639/03 na Rede Municipal de Ensino do Recife. In: AGUIAR, Márcia Angela da S. et al. (Org.). Educação e diversidade: estudos e pesquisas. Recife: Gráfica J. Luiz Vasconcelos, 2009.

SILVA JR, Hédio; BENTO, Maria Aparecida da Silva; SILVA, Mário Rogério (Orgs.). Políticas Públicas de Promoção da Igualdade Racial. São Paulo: CEERT, 2010.

SILVA, Vagner Gonçalves da. Neopentecostalismo e religiões afro-brasileiras: Significados do ataque aos símbolos da herança religiosa africana no Brasil contemporâneo. Mana, Rio de Janeiro, v.13, n. 1, p. 207-236, 2007.

Religiões afro-brasileiras: construção e legitimação de um campo de saber acadêmico. Revista USP, São Paulo, n. 55, p. 82-111, set./nov., 2002.

STF. Audiência pública do STF sobre as cotas raciais nas universidades. Disponível em: $<$ https://www.youtube.com/watch?v=|BfsV3tHoTo>. Acesso em: 10 mai. 2017.

TAVOLARO, Lília Gonçalves Magalhães. Raça, classe e cultura no contexto das políticas de ação afirmativa: um esforço teórico crítico a respeito da raça. Sociedade e Cultura, Goiânia, v. 13, n. 2, p. 287-298, jul./dez. 2010.

\section{Abstract}

This article is a significant part of the Master's research Public Policies with Axé: Afro-Brazilian religions and the promotion of racial equality (demands for the education of Recife), in it we highlight the interfaces between the Black Social Movement and the Afro-Brazilian Religions as a brand Of an ancestry rescued in the 1970s, 80 analyzing the participation of Afro-Brazilian religions in the Racial Equality Conferences and, from the memory of their participation in the 
Conferences, and identifying advances, difficulties and resistance in the implementation of these policies. The intersectionality between the most diverse forms of action in the public sector of the religions of African matrices, through the experience of social control and citizen participation of black women and women from the terreiro (axé women). The Black Social Movement has an indisputable importance in the fight against racism and by affirmation of the rights of the black population, Especially for an education without discrimination, in the questioning of the myth of the racial democracy, including in the 1970s Afro-Brazilian religions as one more element of identity and a milestone in their agenda of claims.

Keywords: Black Social Movement. Afro-Brazilian religions. Black women. Axé women. Policies for the Promotion of Racial Equality. 